\title{
A Literature Review on the Cash Holding Issues
}

\author{
Yulu Ye \\ Accounting Department, Management School, Jinan University, Guangzhou, China \\ Email: yuluye@outlook.com
}

How to cite this paper: Ye, Y.L. (2018) A Literature Review on the Cash Holding Issues. Modern Economy, 9, 1054-1064. https://doi.org/10.4236/me.2018.96068

Received: May 14, 2018

Accepted: June 2, 2018

Published: June 5, 2018

Copyright $\odot 2018$ by author and Scientific Research Publishing Inc. This work is licensed under the Creative Commons Attribution International License (CC BY 4.0).

http://creativecommons.org/licenses/by/4.0/

\begin{abstract}
Corporate cash holding decisions are one of the most important corporate financial decisions. Relevant research has received extensive attention from scholars at home and abroad and has formed rich research results. Starting from the motivation of cash holding, this paper combs and reviews the perspectives of the factors affecting cash holding, and puts forward the issues that we should pay attention to this field.
\end{abstract}

\section{Keywords}

Cash Holdings, Holding Motivation, Influencing Factors

\section{Introduction}

All along, cash has received special attention from companies. Due to the global economic integration and the impact of the international financial crisis, Chinese enterprises generally present tense financial situation. The number of companies that have closed down due to capital chain breaks is not in the minority. From the failure of the Giant Group Shi Yuzhu to the financial crisis of the Delong Group and the insolvency of the Sanjiu Group, these cases have proved the importance of cash for a company. In Fortune magazine in May 2002, Ram Charan and Jerry Useem had put forward the view that the reasons that may cause companies to go downhill are different, but ultimately are all destroyed by the lacking of funds. Coincidentally, after Lenovo Group experienced the financial crisis in 2008, its financial controller Huang Weiming also talked on the interview: "The fact that companies don't have cash is just like people who don't have blood. Even if they have strong capabilities, the company is also difficult to sustain." From this, we can see that the importance of cash flow to the business is self-evident.

Corporate cash holding decisions are very important financial decisions for the company. The level of cash holding of an enterprise not only reflects the business plan and financial strategy of the company, but is even closely related to 
the internal governance of the company and the external macro environment. Companies holding cash can perform good speculation and prevent risks while meeting the needs of daily operations and trading activities. That is, companies can use their cash holdings to seize good investment opportunities, and at the same time, they also can use flexible capital allocation to effectively avoid the risks caused by operating cash flow. But holding cash is necessary to bear the cost. Although cash is highly liquid, it has the lowest profitability compared to other assets. Therefore, when a company holds a small amount of cash, it may miss a good opportunity in the future, and also assume greater operational risks. When the company holds excess cash, it will result in the accumulation of resources and waste, and fail to grasp investment and development opportunities, which may result in decreasing profitability or even losing the dominant position competition in the industry and being eliminated by the market. Therefore, it is very important to explore the problem of cash holding.

The significance and contribution of this paper are two-fold. Firstly, this article mainly reviews and studies the research on cash holding issues, which helps to know the current status of research on cash holding issues and finds defects in domestic related research. Secondly, the systematic review of this paper is also conducive to finding new research directions and further improving the research on cash holding issues.

\section{A Literature Review of the Motivation of Cash Holdings}

The first step in the study of cash holding issues is to understand the cash holding motives. Are companies holding cash for daily operations, risk prevention or speculation? There are many motives for companies to hold cash, and different cash holding motives will affect the company's cash holding decisions. Only understanding the cash holding motive, we can better explore the factors affecting cash holdings.

The academia has long studied the issue of corporate cash holding motivation. As early as 1936, Keynes [1] proposed the theory of cash holding motivation and quickly gained wide attention from the academia. Keynes believes that companies hold cash mainly based on three motivations, which are trading motivation, prevention motivation, and speculative motivation. Trading motivation refers to the cash needs of the company due to daily business operations and transactions. Prevention motivation means that the company needs a certain amount of funds to better cope with emergencies to ensure operational safety. The speculative motivation mainly shows that during the daily business process, enterprises hold more cash to seize good investment opportunities. Later, many scholars have conducted more in-depth discussions on the research area of corporate cash holding motivation based on the Keynes study ever since.

\subsection{Trading Motivation}

The academic research on the issue of cash holding motivation is mainly from 
the perspective of meeting the daily trading needs of the company in the early stage. In the process of commodity circulation, money plays a mediating role and can be exchanged for equal value with other commodities. In the daily production and operation process, companies will involve the purchase of raw materials, equipment, or pay wages, all of which require monetary funds. At this time, companies hold cash mainly based on trading motivation. Baumol [2] proposed that cash reserves can be used as an intermediary for the company to act as a trading medium, and built an inventory model to confirm that transactional money demand would indeed be affected by interest rates to a certain extent. But the premise used in this model is that the amount of corporate cash flow is stable and there is no shortage of funds. Miller and Orr [3] believe that the actual cash demand of the company usually fluctuates widely, and it is difficult to predict accurately. Therefore, the cash flow factor is introduced when constructing the optimal cash holding model.

Himmelberg [4] also constructed a CIA model of cash holding transactional demand on the basis of predecessors. The results of the study showed that labor, material inputs, and inventory rates all have a certain impact on the company's cash holdings. And the data provides empirical support for the trading motivation of the cash holding.

\subsection{Prevention Motivation}

The company holds cash not only to meet the trading needs of daily operations, but also to prevent various uncertain risks. Morris [5] further explores the problem of cash holding by companies under the framework of the Capital Asset Pricing Model (CAPM). The research results show that the low level of cash holding by companies may result in high cost of cash management, that's because when companies hold less funds, they will increase the non-systematic risks caused by uncertainty.

Campbello [6] conducted an empirical study of American companies from 1962 to 1997 and found that when the company's stock volatility was significantly higher than the market volatility. That is, when the company's specific risk was at a relatively high level, the relationship between the stock price of the company presents a decreased trend. Bates [7] found that the average cash-asset ratio of industrial companies in the United States between 1980 and 2006 was more than doubled. The primary reason for this phenomenon is that cash flow risks continue to rise during this period. For the preventive purpose, companies prefer to hold more funds to better cope with the uncertainty risks.

Chinese scholars $\mathrm{Gu}$ and Sun [8] also further explored the relationship between the company's cash holdings and cash flow risks. The empirical research results show that when the company is subject to financing constraints, there is a significant positive correlation between cash flow risk and cash holdings. That is, the higher the cash flow risk, the higher the cash holding level of the company, 
which also supports preventive motivation of holding cash.

\subsection{Speculative Motivation}

Compared with other assets, cash has a very strong feature named liquidity, which can capture good investment opportunities for the company. Therefore, some companies hold cash in order to be able to seize the occasional investment opportunities, which called speculative motivation proposed by Keynes. Myers and Majluf [9] also proposed that cash is valuable. Due to the existence of asymmetric information, the company's financing costs through external channels are generally higher. If the company does not have sufficient cash flow, it may miss good investment opportunities. Therefore, when a company holds $\$ 1$ in cash, shareholders value their value generally above $\$ 1$.

\subsection{Self-Interest Motivation}

In 1986, Jensen [10] proposed the free cash flow hypothesis (FCFT), which put forward new ideas for the company's cash motivation theory-the self-interest motive brought by the agency problem. Jensen believes that due to the existence of an agency relationship, the company will still hold additional cash after meeting daily operations and investment needs. Self-interest motivation focus on managers' fund preference and the abuse of funds, and try to explain the problem of cash holding in the enterprise from the perspective of the agency problem.

With the gradual separation of ownership and control of modern companies, the principal-agent problem between shareholders and management emerged. The goal of managers and shareholders are often inconsistent. Managers can have more detailed and comprehensive information about the company, and they also have personal goals. Cash is the best resource for management to achieve their personal goals. Therefore, managers will tend to hold more monetary funds. For manager's preference for holding large amounts of cash, Jensen further analyzed and found that there were mainly three reasons. Firstly, in order to protect their vested interests and stabilize their status as the manager, managers are more likely to hold more cash. Secondly, managers will be subject to various constraints when using external funds, such as the use of funds, investment interest rates and etc., but it is less restrictive to use of internal funds. Thirdly, the use of high cash can free managers from the supervision of the capital market, and it is more beneficial to achieving their own goals. Therefore, the existence of agency problems makes shareholder's market valuation of the company's $\$ 1$ cash often less than $\$ 1$.

Chinese scholars Liu and Chen [11] found that compared with other companies, the operating performance of the company with high levels of cash holdings was not significantly outstanding, and there were fewer capital expenditures at the later stage. As a result, they believe that in the Chinese market environment, companies' preventive motive of the cash holding cannot be established, and 
the high level of cash holding of the listed company is mainly caused by manager-shareholder agency problems. Wu et al. [12] also proved through empirical data that the main reason for high cash holdings of the chinese listed company is not caused by external financing difficulties. Manager's self-interest and major shareholder's infringement are the most important factors that cause the company to hold large amounts of cash.

\subsection{Commitment Motivation}

On the basis of prevention, some scholars have proposed commitment motivation. They think that the commitment motive of the corporate cash holding considers from the perspective of the client. The client is downstream of the company's entire supply chain, and it is an important stakeholder of the company. Titman [13] suggests that if the company's suppliers or customers are more concentrated, it may need to bear more of the relational investment, and these investments increase the company's financial costs. Companies will refuse to trade with suppliers because they are afraid that the supplier may not be able to provide products on time or ensure product quality. Therefore, suppliers need to hold a certain amount of cash to make commitments to customers to prevent them from falling into financial difficulties due to macroeconomic factors and negatively affecting customers [14].

Jenifer [15] believes that both committed motivation and preventive motivation may lead to an increase in corporate cash holding, but they are essentially different. On one hand, he makes analysis from the point of holding purpose. According to the commitment motivation, the company hold cash to protect the customer's optimal investment and to prevent supply fracture and the loss of unique assets. While for the purpose of prevention, the company holds cash to protect against adverse cash flow shocks. On the other hand, he explains according to the precautionary risk source division. Based on the commitment motivation, the supplier holds more cash to prove to the buyer that the company will not suffer financial crisis or bankruptcy due to economic downturn or other macro environmental factors. And according to the preventive motivation, companies mainly hold cash in order to prevent the business risks caused by the loss of the main customer.

Based on the above points of view, we can find that the motivation for companies to hold cash are various, but no matter what kind of motivations can indicate that cash is valuable. It can ensure that the company operates normally, obtains profits, against risks and so on. Understanding the motivation of cash holding is the basis for the study of corporate cash holding. Different holding motivations affect the company's cash holding decisions, thereby affect the company's cash holdings.

\section{A Literature Review of the Factor Affecting Cash Holdings}

In the process of corporate operations, how much cash should be held is the 
most appropriate for the enterprise? And What factors will influence the corporate cash holding decision. It also has received widespread attention from the academic community. Many well-known scholars have conducted in-depth exploration of the factor affecting cash holdings. However, the research during this period mainly focuses on three aspects: financial characteristics, corporate governance, and financing constraint.

\subsection{Financial Characteristics}

The company's financial characteristics are the most direct factor that affects the company's cash holding level, and many scholars have taken empirical tests on it. Among them, John [16] selected companies from 1979 to 1981 as the research subject. He found that there was a significant positive correlation between the level of the corporate cash holding and Tobin-Q's, R\&D expenses to capital ratio and advertising costs to capital ratio.

Opler et al. [17] also took the empirical research and found that the cash holding level of the company are positively related to future investment opportunities and cash flows. That is, the company with more investment opportunities or cash flows in the future will usually hold more cash, because it is easy to capture good opportunities, which also supports the speculative motivation of the cash holdings. The study also found that when the size of the company or the asset-liability ratio is larger, the corporate cash holdings is lower. The main reason for this phenomenon is that there exists scale effect in cash management. The large companies prefer to diversify their investments, which can reduce the possibility of financial difficulties, so the company holds less cash. Teruel and Solano [18] selected Spanish companies as sample data to take the empirical research. The result shows that corporate cash holdings are obviously positively affected by cash flows and financial leverage, and it has a negative correlation with long-term debt ratio, cash substitutes and short-term bank loans. But they haven't found that corporate cash holdings have any relationship with the growth and the size of the company.

However, $\mathrm{Hu}$ and Jiang [19] used the Chinese data to make a research and found that there is a significant positive correlation between corporate cash holdings and the size of the company. The probable reason is that the large company generally have achieved significant success, so their cash flows are much more abundant. They also found that cash holdings would be negatively affected by cash substitutes, financial leverage and the age of company. Xin and $\mathrm{Xu}$ [20] also used the chinese listed company as the empirical research object. They found that asset turnover, corporate growth, cash flows, and financing needs all have positive impacts on corporate cash holdings.

\subsection{Corporate Governance}

Corporate governance is also a hot influencing issue in the academic community on the cash holding. Corporate governance factors are mainly divided into 
external and internal governance factors. External factors include national or regional laws, market conditions and so on, and internal factors include the board of directors and governance structure.

In the aspect of external factors, Pinkowitz et al. [21] selected the company with malicious acquisition from 1985 to 1994 as the research object. The result showed that the company that is much more likely to be acquired hold the less cash. Dittmar et al. [22] also found that compared with the company that is in a good equity environment, the company with a good equity environmen hold less cash. They also put forward that in the country with poor protection of shareholders' rights, information asymmetry and investment opportunity do not have a significant impact on corporate cash holding behaviors. The main reason is that shareholders are in a weak position and their rights are not well protected, so shareholders cannot effectively supervise managers to assign the excess cash to them. Chen, Li and Wang [23] used Chinese empirical data and then found that the quality of regional government has a negative relationship with the corporate cash holdings. They also found that the private companie's behaviors about cash holdings are more sensitive to the quality of the government. For the state-owned enterprise, as the actual controller's administrative level is continuous improved, That corporate behavior on cash holding is affected by the quality of the governmentis gradually reduced.

About the research on internal factors, Harford et al. [24] took the American companies between 2000 and 2004 as the research object, and they found that the level of cash holding is positively related to Corporate governance. When the corporate governance is better, its cash holdings are higher. when corporate governance is in good condition, the power of shareholders is stronge and the agency problem are also eased. At this time, shareholders can well supervise the manager to hold more cash. Ozkan [25] also used empirical research to prove that with the increasing proportion of the managers' shareholding, the company's cash holding level shows a trend of falling first, then rising and then falling. Chinese scholars Zhang and Liu [26] selected three variables as the substitute variable of the shareholder protection. These variables include absolute shareholding ratio of the largest shareholder, relative shareholding of the largest shareholder and ownership type. The result indicates that there is a significant negative correlation between shareholder protection and corporate cash holdings.

\subsection{Financing Constraint}

In addition to financial characteristics and corporate governance, financing constraint is also a very important factor to affect cash holdings. In 1999, Opler [17] had begun to study the effect of the financing constraint on cash holdings. He chose american companies as the research subject and selected the debt level to measure the corporate financing constraint. This research indicats that the company with financing constraints hold more cash than the company without 
financing constraints. Later, some scholars also took the empirical research to supporte Opler's viewpoints. They found that compared with non-financing constrained companies, corporate cash holdings are more sensitive to cash flow in financing constrained companies. They also found that the company with financing restraints would like to retain more cash as future reserves, and this phenomenon will be more apparent during the period of financial depression [27] [28].

Han and Qiu [29] built a two-stage investment model to conduct in-depth research on the issue of cash holdings. The results of the study shows that the cash holding of the financing constrained company is more sensitive to the fluctuation of cash flow.And they will hold a large amount of cash to prevent cash flow risks. However, this relationship is not significant in non-financially constrained companies. Dittmar and Smith [30] used american companies as empirical research objects. They chose diividend payment rate and bond rating to measure the constraints of corporate financing and found that compared with non-financing constrained companies, financing constrained companies have higher value of the cash holding. This also indicates that financing constraint does have a certain impact on the company's behavior about cash holding. Faulkender and Wang [31] divided the sample company into two groups through various indicators, such as the size of the company and dividend payout ratio. The result shows that the company with financing constraints would have stronger dependence on internal cash reserves, and thier cash holdings are generally higher than the company with non-financing constrains. For this phenomenon Faulkender and Wang explain that when companies are limited by financing constraints, it is more difficult to obtain cash from the outside and the enterprise need to rely on cash flows generated in the company.So there will be better incentives to make the company to hold much more cash.

Luo and Wan [32] selected the Chinese listed company from 2004 to 2006 as the sample object, and found that the corporate cash holdings have a U-shaped relationship with the debt situation. The further research represents that the level of corporate cash holding has a positive relationship with the short-term debt ratio, and has a significant negative correlation with the long-term debt ratio. It shows that the length of the debt will affect the corporate behavior on cash holding. They analyzed the sources of debt to find that cash holdings has negatively correlated with bank liabilities, but it is positively correlated with the commercial credit ratio.

\section{Conclusions}

In this paper, I systematically comb all the researches about the cash holding from the aspects of holding motivation and influencing factors, which can help us to increase the understanding of the status of the cash holding, and also can help to discover new research ideas for cash holdings. However, due to the 
author's research ability and the limitations of the article's length, there are still some deficiencies, including these following points:

1) This article only collates research on holding motivation and influencing factors, and fails to systematically sort out all the studies about the cash holding issues.

2) This paper fails to further analyze the theoretical basis of cash holdings.

Based on the above discussion, we find that foreign academic research about cash holdings is very comprehensive, and they already form wealth research results. However, the Chinese academic community has not paid enough attention to this issue, and relevant literature that is in normative research or empirical research is scarce.

The Chinese economic environment is very different from Western countries. If we directly transplant the foreign empirical conclusions to China, it will lack persuasion. With the development of the capital market, it's undoubted for China that the foreign research can provide a certain theoretical basis and research method to study the cash holding issus. Therefore, there is a lot of space for research in this area, and the future research directions mainly include these following points:

1) Closely combine the theory with the practice. Compared to foreign countries, China has major flaws in its management rule, legal system and market condition, which will have a significant impact on the company's decisions of the cash holding. So we must pay attention to the analysis of Chinese national conditions in the future research, and continuously modify the cash holding decision factor model. At the same time, we must also focus on improving empirical research in China.

2) Throughly consider the factor influencing cash holdings. At this stage, the research on the influencing factors of cash holding carries out from two aspects. One is the internal characteristics of the company, and the other is the macro-economic factors. However, supplier and customer are in the upstream and downstream of the company, and they are the important external stakeholders for the company, and they also have a significant impact on business operations and financial decisions. Therefore, it has great significance to explore the impact of supplier-customer relationships on cash holdings.

3) Further distinguish motives of the corporate cash holding. In the actual situation, the company's behaviors about cash holding are a very complicated process, which is affected by many factors, so the enterprise should need to consider multiple perspectives to detemine the cash holding level. But which motive is the main factor in a certain situation and which one is the secondary? We can further distinguish these motives. At the same time, it cannot be ignored to pay attention to studying the interaction between these various motives.

\section{References}

[1] Keynes, J.M. (1937) The General Theory of Employment. Quarterly Journal of Economics, 51, 209-223. https://doi.org/10.2307/1882087 
[2] Baumol, W.J. (1952) The Transactions Demand for Cash: An Inventory Theoretic Approach. Quarterly Journal of Economics, 66, 545-556. https://doi.org/10.2307/1882104

[3] Miller, M.H. and Orr, D. (1966) A Model of the Demand for Money by Firms. Quarterly Journal of Economics, 80, 413-435. https://doi.org/10.2307/1880728

[4] Himmelberg, C.P. (2003) Cash Holding at the Firm Level: Can Transaction Costs Explain It All? Working Paper.

[5] Morris, J.R. (1982) The Role of Cash Balances in Firm Valuation. Journal of Financial \& Quantitative Analysis, 18, 533-545. https://doi.org/10.2307/2330946

[6] Campello, M. (2003) Capital Structure and Product Markets Interactions: Evidence from Business Cycles. Journal of Financial Economics, 68, 353-378. https://doi.org/10.1016/S0304-405X(03)00070-9

[7] Bates, T.W., Kahle, K.M. and Stulz, R.M. (2009) Why Do U.S. Firms Hold so Much More Cash than They Used to? Journal of Finance, 64, 1985-2021. https://doi.org/10.1111/j.1540-6261.2009.01492.x

[8] Gu, N.K. and Sun, J.J. (2009) Financing Constraints, Cash Flow Risks, and Preventive Motivations for Cash Holdings. Journal of Business Economics, 210, 73-81.

[9] Myers, S.C. (1984) The Capital Structure Puzzle. The Journal of Finance, 39, 574-592. https://doi.org/10.1111/j.1540-6261.1984.tb03646.x

[10] Jensen, M.C. (1986) Agency Cost of Free Cash Flow, Corporate Finance. American Economic Review, 76, 323-329.

[11] Liu, X.Y. and Chen, P. (2008) The Research on Long-Term High Cash Holding Motivations of Listed Companies in China. South China Journal of Economics, 11, 50-60.

[12] Wu, X.X., Zhan, Z.H. and Zhang, Y.Q. (2007) An Empirical Study on the Motivation of Cash Holdings by Listed Companies in China, Based on the Perspective of Capital Market Information Asymmetry. Journal of Shanxi University of Finance and Economics, 11, 88-93.

[13] Sheridan, T. (1984) The Effect of Capital Structure on a Firm's Liquidation Decision. Journal of Financial Economics, 13, 137-151. https://doi.org/10.1016/0304-405X(84)90035-7

[14] Bao, Q. and Zhao, X.Y. (2015) Supply Chain Relationship Trading and Financial Flexibility Reserve Motivation: "Commitment" or "Prevention". Finance and Trade Research, 26, 150-156.

[15] Itzkowitz, J. (2013) Customers and Cash: How Relationships Affect Suppliers' Cashing Holdings. Journal of Corporate Finance, 19, 159-180. https://doi.org/10.1016/j.jcorpfin.2012.10.005

[16] John, T.A. (1993) Accounting Measures of Corporate Liquidity, Leverage, and Costs of Financial Distress. Financial Management, 22, 91-100. https://doi.org/10.2307/3665930

[17] Opler, T.L., Pinkowitz, R.S. and Willamson, R. (1999) The Determinants and Implications of Corporate Cash Holding. Journal of Financial Economics, 52, 3-46. https://doi.org/10.1016/S0304-405X(99)00003-3

[18] Teruel, P.J.G. and Solano, P.M. (2004) Impact on the Determinants of SMEs Cash Holding: Evidence from Spain. Working Paper.

[19] Hu, G.L. and Jiang, Y.M. (2005) Factors Affecting Cash Holding Decisions-Proven from B-Share Companies. Journal of Hunan University, 649-654.

[20] Xin, Y. and Xu, L.P. (2006) Factors Affecting the Level of Cash Holdings of Listed 
Companies: Financial Characteristics, Ownership Structure and Governance Environment. China Accounting Review, 2, 307-320.

[21] Pinkowitz, L., Billett, S. and Dahiya, P. (2000) The Market for Corporate Control and Corporate Cash Holdings. Georgetown University, Washington DC.

[22] Dittmar, A., Mahrt, S.J. and Servaes, H. (2003) International Corporate Governance and Corporate Cash Holdings. Journal of Financial \& Quantitative Analysis, 38, 111-133. https://doi.org/10.2307/4126766

[23] Chen, D.Q., Li, S.F. and Wang, C. (2011) Government Quality, Ultimate Property and Corporate Cash Holdings. Management World, 11, 121-141.

[24] Harford, J., Mansi, S.A. and Maxwell, W.F. (2008) Corporate Governance and Firm Cash Holdings in the US. Journal of Financial Economics, 87, 535-555. https://doi.org/10.1016/j.jfineco.2007.04.002

[25] Ozkan, A. and Ozkan, N. (2004) Corporate Cash Holdings: An Empirical Investigation of UK Companies. Journal of Banking and Finance, 28, 2103-2134. https://doi.org/10.1016/j.jbankfin.2003.08.003

[26] Zhang, R.J. and Liu, C.J. (2005) Ownership Structure, Shareholder Protection and Corporate Cash Holdings. Finance \& Trade Economics, 2, 3-9.

[27] Almedia, H., Campello, M. and Weisbach, M. (2004) The Cash Flow Sensitivity of Cash. The Journal of Finance, 59, 1777-1804. https://doi.org/10.1111/j.1540-6261.2004.00679.x

[28] Arslan, O., Florackis, C. and Ozkan, A. (2006) The Role of Cash Holdings in Reducing Investment-Cash Flow Sensitivity: Evidence from a Financial Crisis Period in an Emerging Mark. Emerging Markets Review, 7, 320-338. https://doi.org/10.1016/j.ememar.2006.09.003

[29] Han, S.J. and Qiu, J.R. (2007) Corporate Precautionary Cash Holdings. Journal of Corporate Finance, 13, 43-57. https://doi.org/10.1016/j.jcorpfin.2006.05.002

[30] Dittmar, A. and Mahrt-Smith, J. (2007) Corporate Governance and the Value of Cash Holdings. Journal of Financial Economics, 83, 599-634.

https://doi.org/10.1016/j.jfineco.2005.12.006

[31] Fualkender, M. (2004) Cash Holdings among Small Business. Working Paper.

[32] Luo, J.H. and Wan, D.F. (2008) The Research on the Effect of Debt Financing on Corporate Cash Holdings-Evidence from Chinese Listed Companies. Journal of Shanxi University of Finance and Economics, 9, 119-124. 